\title{
The promotion of health and beauty tourism through websites: a linguistic analysis
}

\author{
$M^{a}$ Enriqueta Cortés de los Ríos ${ }^{1}$ \\ Universidad de Almería
}

\begin{abstract}
Ana Corral Hernández
Universidad de Granada
\end{abstract}

\begin{abstract}
In addition to magnificent beaches, history and culture, tourism websites also offer health and beauty centres for the tourists' wellbeing. This study examines the discourse for the promotion of health and beauty tourism. The purpose of this paper is to offer a general view of this type of discourse focusing on its linguistic resources (lexical-morphological, syntactic and stylistic) in order to better understand its main distinctive features. With this aim in mind we have analyzed websites related to the promotion of health and beauty tourism in Andalusia in English versions. The results of this study can be of relevance both to professional translators and particularly to students and teachers of translation, bearing in mind the emergence of health and beauty tourism as a new type of specialized discourse and the increasing probability that translators will be faced with texts of this nature.
\end{abstract}

Keywords: tourism discourse, promotion, linguistic resources, advertising discourse

1 Corresponding author - Universidad de Almería, Departamento de Filología, C/ Sacramento s/n, La Cañada de San Urbano, 04120 Almería (España).

Email: mecortes@ual.es 


\section{RESUMEN}

Además de magníficas playas, historia y cultura, los sitios web de turismo también ofrecen centros de salud y belleza para lograr el bienestar de los turistas. Este estudio analiza la promoción del discurso turístico de salud y belleza. El propósito de este artículo es ofrecer una visión general de este tipo de discurso centrándonos en sus recursos lingüísticos (léxico-morfológicos, sintácticos y estilísticos) con el fin de comprender de manera óptima sus principales rasgos distintivos. Con esta idea hemos analizado sitios web en versión inglesa relacionados con la promoción del turismo de salud y belleza en Andalucía. Los resultados de este estudio pueden ser relevantes para los traductores profesionales y particularmente para los estudiantes y profesores de traducción, teniendo en cuenta que la aparición del turismo de salud y belleza ha dado lugar a un nuevo tipo de discurso especializado con el que, con gran probabilidad, se enfrentarán los traductores.

Palabras clave: discurso del turismo, promoción, recursos lingüísticos, discurso publicitario

\section{Introduction}

Tourism discourse is a type of specialized discourse typically characterized by stylistic choices and linguistic strategies of persuasion (Cappelli, 2006; Gotti, 2006). Persuasion is a function that permeates a variety of genres within travel and tourism (Mapelli, 2008; Pierini, 2009; Suau Jiménez, 2012). This type of discourse is mainly characterized by its terminology, which differentiates it from other specific languages. The heterogeneity of the topics and different tourism segments turn it into a multidisciplinary language featuring great lexical variety.

The popularization of the Internet makes tourism websites a suitable approach to gain more travelling information and attract more potential tourists. It offers a large amount of information concerning tourism. As tourist texts are a kind of promotional text, they fall within the category of advertising discourse, thus sharing similar techniques like using persuasion to encourage consumption.

This study examines the promotion of the health and beauty tourism discourse from the register approach. The purpose of this paper is to offer a general view of this type of discourse focusing on its linguistic resources (lexical-morphological, syntactic and stylistic) in order to better understand its main distinctive features. The results of this study could be helpful for professional translators and translation trainees. With this aim in mind we have analyzed websites related to the promotion of health and beauty tourism in Andalusia in English versions. All of them have been designed by experts in tourism and are addressed to readers who look for some information to organize their health and fitness holidays. Bearing in mind the emergence of health and beauty tourism as a new type of specialized discourse and the increasing probability that translators will be faced with texts of this nature, we think that 
familiarizing our students with its linguistic characteristics can help them to better convey their communicative purpose.

This paper is divided into several sections. The first two give an overview of the preliminary aspects of this study. Next, the corpus under analysis and the methodology used will be introduced. Then, the linguistic characteristics of the analysis will be presented. Finally, in the last section, a set of conclusions will be drawn.

\section{Tourism and advertising}

The language of tourism is part of tourism discourse. Tourism promotion is an essential source of information for the potential tourists. It engages people in decision-making concerning the destination they would like to travel to (Salim et al., 2012).

Tourism discourse is a type of specialized discourse and as a result its texts present a specific nature. According to Cabré Castellví (1993, p.151):

Specific texts contain regular linguistic features at each level of grammar, such as those that are graphic-phonologic, morpho-syntactic and lexicosemantic, also including a lexical choice, presence and absence of concrete units and structures, and the use of diverse codes. In this sense, they usually show particular linguistic patterns and units, such as foreign words that are transformed into English words, complex noun groups, adjectives in noun premodifying patterns, verbs in the indicative mode, the present tense, neologisms, borrowings, learned terms, group units, abbreviations, acronyms, specialized borrowings, nouns derived from verbs and short sentences.

Later Dann (1996) stated that tourism discourse is defined by the wide usage of verbal means which persuade, attract, lure and seduce a lot of people by means of adjectives, emphatic language, metaphors, epithets, hyperboles and other stylistic devices, imperative mood, rhetorical questions, etc.

This type of discourse is characterized by the presence of emphatic phrases and highly evocative adjectives, and addressees are constantly involved by means of direct exhortations. Syntactic and lexical choices are never casual, but they reflect precise intentions of the addresser, who aims to impress, promote and attract (Zuliani, 2013).

Different modes of communication are found in tourism discourse. Thanks to the Internet new modes have appeared. Tourist electronic texts are expressive, vivid, persuasive and iconic at the same time. As Skibitska (2013) affirms, the tourist web 
text can be regarded as the combination of verbal and non-verbal signs pursuing the objective of informing, convincing and luring the target recipient, i.e. notifying the addressee of the existence of some tourist product and then persuading them to use it (buy tickets, book a hotel room, visit a country, see a sight, etc.). Therefore, the source text author should use imperative sentences, direct or hidden orders, leading and prompting questions.

As all languages have to be learned, the language of tourism, too, requires a process of socialization for those who generate it and those who translate it. It is claimed that tourism is also referred to as communication, advertising, publicity and promotion (Merkaj, 2013).

Together with television ads and advertisements in newspapers and magazines, tourist discourse is a type of advertising discourse (Zuliani, 2013). Genres like websites offering information about different aspects related to tourism promotion adopt similar communication techniques to this type of discourse. The tourist advertising text par excellence is the tourist brochure and, as Calvi (2009) states, the style of web portal texts is very close to that of brochures. This genre "does not sell" products, but landscapes, nature, entertainment, desires, pleasure, etc. Ponderative forms and connotative descriptions with recurring formulae are very common on websites characterized by a major involvement of the addressee in an indirect or exhortative way. As a result, there is a preference for linguistic strategies of persuasion.

Persuasion as a communicative strategy is usually present in everyday situations. Schmidt and Kess (1986, p. 2) define it as "the process of inducing a voluntary change in someone's attitudes, beliefs or behaviour through the transmission of a message". Persuasion is needed to influence potential tourists. Through the tools of persuasion, verbal messages deliberately intend to affect the hearts and minds of the audience. Investigations into persuasion in the tourism context have been carried out by scholars such as Priester \& Petty (2003), who are concerned with how persuasion is reflected in the verbal message.

Different scholars have analyzed advertising persuasion from different points of view (Leech, 1996; Fuertes-Olivera, Velasco-Sacristán, Arribas-Baño \& SamaniegoFernández, 2001; Cortés de los Ríos \& Azzahraa, 2014, among others). Advertisers often use rhetorical devices, techniques and strategies to achieve their goals of moving their audiences and/or changing their attitudes. The AIDA model is principally used in marketing as a way of describing the four stages that people go through when accepting a new idea or buying a new product. The reasoning behind this model is that communication should first attract the receiver's Attention, then engage the receiver's Interest, then create in the receiver a Desire for the product or 
service, and then provoke Action in the receiver. This model is applied to the discourse of tourism promotion. As Morgan \& Pritchard (2000) state, any organization involved in the leisure and tourism business, from local arts centres, museums, sports clubs, and small hotels to the largest theme parks, airlines and cruise companies, will be interested in advertising in one form or another. In the same vein, Skibitska (2013) affirms that tourist websites can be informative, promotional, and commercial, or a combination of all of them. Anyone can see that their main objective is to advertise the destination, site or product so that it may reach the customer.

\section{Advertising and translation}

In the last years we have witnessed a significant increase in the demand for translation, as more and more languages are being promoted nowadays. This may be explained for a number of reasons, including the need to assert the national identity of their speakers, the true revolution in technology, namely the Internet and the social media, the steady rise in literacy, and the improvement of transport and communication spreading all over the world, to name but a few. It is stated that all these facts and achievements have contributed to the exponential growth and increased demand for translation. This tendency has accelerated dramatically, so we have faced a rehabilitation of translation as an essential element in exporting tourism and the business of international organizations and institutions (Picken, 1989).

It is in this sense that advertising serves the requirements that the business world has set today to expand its sphere of action into a more tangled web. In other words, the internationalization of markets has increased the need for translating advertisements after buying and selling have become a globalized phenomenon. Advertising increases product demand in a market sector, thus encouraging consumption. To serve this common goal, advertising translation has become an indispensable tool to communicate, to publicize either a service or a product by way of promoting and selling a certain brand.

Likewise, as Valdés Rodríguez (2013) points out, advertising translation plays a key role in determining the marketing process of a company since the wider the advert gets, the more potential customers can be persuaded to buy the product. The marketing strategies of a company are mirrored in the approach the translator has to convey in the target language, thus making the translation highly dependent on the business concept devised by that company.

We also have to take a closer look at the effect of the target text on the receiver, as 
the text is rendered for a specific purpose, making it strongly determined by the needs and expectations of the potential customer.

Tatilon (1990) assumes that the formal dimension of an advertising text fulfills two main functions, namely that of entertaining and enjoying and a mnemonic one related to memorizing and reading the text. Given that our present study deals with the topic of health and wellness, the promotional material in our corpus reflects the ideas of enjoying and feeling better by way of the so-called media mix, that is, the combined use of different media to make the information more and more appealing. The use of language also emphasizes maximum exposure in order to get the message across by being highly direct and persuasive.

In this sense, authors like Torresi (2007) became aware of the importance of visual elements in advertising translation, which define the intersemiotic nature of advertisements and the consequences in the target text. Cruz García and Adams (2005) wrote about the implications of verbal and iconic components for the translation of advertisements. And later on, Adams and Cruz García (2007) affirmed that the image is accompanied by little or no text and the message is transmitted by the connotative power of the values associated with the image.

Following Valdés Rodríguez's views (2013), new technologies, specifically the Internet, have brought about changes in audiovisual texts, subordinating them to their ultimate effect in the target audience. Numerous studies have analyzed the advertising of consumer products so as to determine the specific uses of the language and the relevance of the image in the transmission of the message in an advertisement. Cruz García and Adams (2006) explain that the social and cultural context in which the advertisements are produced also plays an important role in shaping the use of a certain language.

Having mentioned the correspondence between the image and the language used in the promotional text, Zuliani (2013) suggests that the web portal can be defined as a "hybrid genre", drawing together discursive strategies and structures from other tourist text types. In real fact, these strategies and structures are adapted to navigation needs and are enriched with interactive resources which are not available in printed paper.

Websites can be considered as a macro-genre, since all of them share common and recognizable features, namely a title bar, navigation, a main content area, subsections, links, how to contact, FAQs, etc. The user chooses what to read and not necessarily in the order of a printed text as entry and exit pages replace beginning and end. Links relate different texts and act as a cohesive device to maintain web discourse together. The language used gives some hints about the content of the web pages in the form of keywords, key phrases and full sentences or short texts, 
acting as contributors to determine the visibility of the information presented as to the ranking in the results of search engines (Cappelli, 2008).

Moving on to the specific purpose of our study, that is, analyzing promotional material from health and wellness-related websites, we should be aware that these pages are usually translated and today the role of the translator has dramatically changed. The translator has to convey faithful information about the cultural references included in the source text and not only the linguistic and pragmatic expertise of the target language, but also the intercultural knowledge that the tourist phenomenon involves (Borrueco, 2006).

It is really difficult to assess the quality of web translations and this fact makes a difference as to the impact of a certain website, being eventually the translator responsible for the success or failure of the business advertised. Cappelli (2008) poses the question of how to call the process to achieve the target text: translation, localization, or adaptation, bearing in mind that the web content is not an online version of a printed document. Translating the web turns into a complex task involving different analyses, skills and language idiosyncrasies. In this sense, she supports the idea that web translation is a type of specialized translation, specifically the translation of tourist-related web pages as regards the specificities of the language of tourism and of the technical features of the media. Translation training has been revolutionized by the wide range of possibilities afforded by the Internet (Jiménez Crespo, 2015). Capelli (2008) studies the way the term 'localization' has evolved, from certain processes available in localizing software to a new approach to translating. This perspective entails analyzing textual, discursive, pragmatic or structural features present in web texts, and how that economic and technological process of localization influences translation today. This recent technique requires updating technical competences on the part of translators as well as knowledge of the textual conventions present in hypertexts.

The competence model in localization (Folaron, 2006, cited in Jiménez Crespo, 2008) includes subcompetences:

- management of localization schemes

- management of computer tools for translation as well as basic knowledge of programming languages

- cultural and linguistic subcompetences associated to translation in general.

Moving on to the issue of quality in translation, Chaume Varela \& Martí Ferriol (2014) point out the necessity of teaching advertising translation to university students on the grounds that new subjects should be designed to respond to emerging market needs so that additional training for translators working in this area can be 
provided. Advertising translation plays a key role nowadays in Translation study programs and both university lecturers and students (undergraduates and postgraduates) have become aware of its relevance in the translator's professional career.

\section{Corpus and methodology}

Tourism in Andalusia has many different channels of tourist promotion, such as websites, brochures, leaflets distributed by tourist agencies and promotional videos. For our purposes, we have selected some official and unofficial tourism websites offering a clear view of the promotion of health and beauty in this region of Spain. This study consists of a corpus-based analysis of websites promoting this type of tourism in Andalusia during 2015.

The compilation of a corpus requires the definition of a set of variables in the design phase according to the purpose of the research project. In our specific case, a number of criteria were determined, following Bowker \& Pearson (2002: 54), as can be seen in table 1 below:

\begin{tabular}{ll}
\hline Criterion & Criterion specification \\
\hline Temporal criterion & $\begin{array}{l}\text { The date of publication or } \\
\text { creation of the texts selected is } \\
\text { as recent as possible. }\end{array}$ \\
\hline Geographical criterion & $\begin{array}{l}\text { All the texts selected are } \\
\text { geographically limited, that is, } \\
\text { all the texts used are from } \\
\text { Andalusia, Spain. }\end{array}$ \\
\hline Formal criterion & $\begin{array}{l}\text { The texts selected pertain to a } \\
\text { specialized communicative } \\
\text { setting and are in full } \\
\text { electronic format. }\end{array}$ \\
\hline Genre or textual typology & $\begin{array}{l}\text { All the texts selected belong to } \\
\text { the same genre, that is, } \\
\text { tourism promotion. }\end{array}$ \\
\hline criterion & $\begin{array}{l}\text { All the texts are documents } \\
\text { drafted by official institutions } \\
\text { authorship criterion }\end{array}$ \\
& and private companies. \\
\hline
\end{tabular}

Table 1. Set of criteria used in the compilation of the corpus.

The corpus of our study consists of the following official and unofficial websites which are popular and accessible: 
(1) Official website

http://www.andalucia.org. This is the official tourism website in Andalusia. We have focused on the section related to health and beauty. It contains information about Types of Waters, Therapeutic treatments, Arabic baths, Spas, Accommodation with SPA, Health And Beauty Center search.

\section{(2) Unofficial websites}

http://www.balnearioalhamadegranada.com. It gives information about spa and thermal water in the Hotel Balneario Alhama de Granada.

http://www.balneariosanandres.com/. It offers high quality water therapies in Canena (Jaén).

http://cordoba.hammamalandalus.com. It promotes Arab baths in Córdoba offering baths and massages.

http://málaga.hammamalandalus.com. It promotes Arab baths in Málaga offering baths and massages.

http://granada.hammamalandalus.com. It promotes Arab baths in Granada offering baths and massages.

http://balneariodelanjaron.com/. It promotes a Spa Center in Lanjarón. It offers health programs, thermal baths, showers, massages, thermal beauty treatments, thermotherapy, minero-medicinal waters.

http://www.balnearios.org/en/balneario/chiclana. It promotes medicinal waters, therapeutic treatments and thermal technics in Chiclana, Cádiz.

http://www.villapadiernathermascarratracags.com/es/termas. It promotes Arab baths in Carratraca, Málaga. It offers services in thermas, massages and treatments.

http://www.airedealmeria.com. It promotes Arab baths in Almería. It offers baths, massages and wellness treatments.

http://www.airedesevilla.com. It promotes Arab baths in Sevilla. It offers baths, massages and wellness treatments.

As to methodology, we will follow register analysis to study the language of the promotion of health and beauty through the above websites. This approach focuses on the structural elements (lexis and syntax) which constitute the backbone of these texts. To this end, this paper follows the research lines of Alcaraz Varó (2000). This approach, described by Halliday, McIntosh \& Strevens (1964), is defined as the 
variety of a language in which a set of lexical and grammatical features stands out. Due to the frequency and regularity with which these are repeated, there is a certain sense of a differentiated unit (Dudley-Evans \& St. John, 1998; Alcaraz Varó, 2000). From this structuralist perspective, we will identify the lexical-morphological, syntactic and stylistic features which stand out in the texts selected. In order to illustrate the most significant peculiarities of these persuasive texts we have chosen and explained some samples from tourism websites.

\section{Linguistic analysis}

In order to carry out a linguistic analysis of the most recurring and significant aspects of health and beauty tourism, we have focused on lexical-morphological, syntactic and stylistic resources.

\subsection{Lexical-morphological resources}

One of the recurrent features of the language of health and beauty tourism is the use of specialised vocabulary and lexical collocations, like osteopathy, chiromassage, mud baths, steam rooms, skin rejuvenator, thalassotherapy spa, algae cures, contrast showers, heat chairs, jet spray massage, spa cure, steam baths, foot reflexology or Turkish bath.

On the other hand, positive adjectives are very common in order to arouse the tourist's desire, like bubbling, rejuvenating, exfoliating, purifying, oxygenating, curative, medicinal, refreshing, revitalizing, relaxing, analgesic and toning. Some examples taken from the corpus are bubbling massage, rejuvenating facial massages, exfoliating massage, purifying properties, oxygenating spa, curative properties, medicinal thermal waters, refreshing and revitalizing treatment, relaxing, analgesic and toning action.

The concepts of authenticity and uniqueness are also found in this type of discourse by means of other adjectives like genuine and unique, e.g. a genuine mineral water Spa or unique waters. It is remarkable that the concept of authenticity and uniqueness is used to awaken in the traveller the desire of enjoying something real and with no equal. An example taken from the corpus is shown below:

\section{Purchase any of our packages with a gift card and surprise your loved} ones with a unique experience (granada.hammamalandalus.com).

Positive adjectives are created by means of affixes. The prefixes -anti and -re are used in the description of characteristics of thermal waters and health and beauty treatments like anti-inflammatory, anti-allergic, re-equilibrant, re-moisturizing, antitoxin, anti-nicotine, anti-cellulite or anti-alcohol. Although -anti assumes to carry 
negative evaluations, its value is inverted culturally in order to convey positive meaning. The ways the positive adjectives are used illustrate the positivity of the product. This will be imprinted on the reader's mind by means of what Cook (2001, p. 108) refers to as "fusion that will imbue the characterless product with desirable qualities". Positive adjectives are used to highlight certain qualities and values in products. In short, the use of emotive adjectives or adjectival phrases can stimulate fantasy, dreams and desires. See an example of the adjectives with affixes taken from the corpus:

$$
\begin{aligned}
& \text { Thermal waters have many benefits ... as well as analgesic, anti- } \\
& \text { inflammatory, anti-allergic, re-equilibrant, re-hydrating, anti-toxin, anti- } \\
& \text { oxidizing and sedative properties (balnearioalhamadegranada.com). }
\end{aligned}
$$

Another peculiarity is the use of loan words. This technique is used in advertising discourse to emphasize the origin of the product or its exclusiveness in relation to a particular country. In the discourse of health and beauty tourism Japanese terms are given to describe showers or therapies like shiatsu showers and reiki therapy. This practice offers an exotic image to the visitor and evokes a stereotype of the Asian culture highly appreciated among the people who look for the wellbeing of the body and mind. On the other hand, French terms like massage and masseur are also very common. Examples taken from the corpus are the following:

$$
\begin{aligned}
& \text { The Spa Circuit Plus add to the Spa Circuit the thermal water jet, a } \\
& \text { pleasant massage with relaxing thermal water and tones the muscles, } \\
& \text { relieving pain (balnearioalhamadegranada.com/en-GB/terapias.aspx). } \\
& \text { Our masseur will ask you if you wish to receive the massage on your } \\
& \text { legs, back or on both areas } \\
& \text { (granada.hammamalandalus.com/en/services/bath-and-massage). }
\end{aligned}
$$

Instances of genre-mixing have been found in our corpus in texts intended for the general public, specifically the use of terminological specialised units taken from science when promoting properties and benefits of different types of water, such as mineralisation, sulphates, bicarbonates, sodium, chloride, calcium and magnesium. The use of this terminology is widely employed in order to gain prestige. The aim of this technique is to make this type of discourse more attractive to readers, encouraging them to use the product as something reliable.

In the creation of new words we can observe the tendency to use blends to speak for example about different types of therapy. A blend consists of combining two words to create a new one like balneotherapy and thalassotherapy.

On the other hand, there is frequent use of direct address for both ideological and practical reasons. The use of the second-person personal pronoun seeks to address 
the potential visitors directly by creating a friendly atmosphere. Thus, people become individual addressees rather than part of a mass audience, which is highly valued. This handling of people on an individual basis is referred to as 'synthetic personalization' (Fairclough, 1989, p. 62). Some examples are shown below:

Welcome to the world of spas. Here you will find medicinal, mineral-rich waters, facilities ideal for personalized treatments and specialist medical teams (andalucia.org/en/health-and-beauty/spas).

Andalusia's excellent climate, the pure air of its mountains and the refreshing sea breeze will help you enjoy every second as you take care of yourself (andalucia.org/en/health-and-beauty).

The use of acronyms is not very frequent in tourism discourse. However, we can highlight two of them which are very characteristic of the analyzed sector. The proper terms SPA (Salutem Per Aquam) and VIP treatment, this latter often accompanied by the image of a crown. Positive connotations are activated by means of this icon, which transmits luxury and glamour to the tourist by means of metonymy.

Another recurrent linguistic feature in this corpus is compound nouns, combinations of words which are very common in everyday language, and are invented on a daily basis. They are very productive in this type of discourse since they provide lots of information within a considerably reduced space. Compound nouns can be words written together, words that are hyphenated, or separate words that are connected by their meaning. Sometimes, the hyphen disappears as the word is more widely used, thus becoming a closed word. Its meaning is often different from the meaning of the two separate words, or more specific. See the following examples:

$$
\text { medicinal-mineral (villapadiernathermashotel.com/BROCHINGLlow.pdf) }
$$

$$
\begin{aligned}
& \text { A perfect setting to recover the necessary calm and wellbeing } \\
& \text { (balnearioalhamadegranada.com). }
\end{aligned}
$$

\subsection{Syntactic resources}

As for syntax, second person imperatives are used in the description of spas and health treatments section to persuade potential customers.

Enjoy a refreshing bath accompanied by a relaxing massage (cordoba.hammamalandalus.com).

In addition, it is also interesting to note that this peculiarity is used to prompt the involvement of the tourist by means of an "invitation" to act quickly. In (10) an 
illustration is given by an imperative sentence offering diverse options to "grasp" the product (Arab bath):

$$
\begin{aligned}
& \text { Make your reservation online, by calling +34 } 9522150 \text { 18, email } \\
& \text { malagareservas@hammamalandalus.com or directly at our reception in } \\
& \text { Martyrs Square } 5 \text { (malaga.hammamalandalus.com). }
\end{aligned}
$$

This technique is very frequent in advertising discourse. It is crucial that the advertiser induces potential customers to act now. We should remember that "to provoke action" is a function of the AIDA model.

Recurring verbs in the present tense are used in this type of discourse. Some of them show this characteristic by making reference to the skin, like nourish, moisturize, prevent, soften, refresh and pamper. On the other hand, the corresponding adjectives of these verbs are also used: nourishing, moisturizing, preventive, soft, refreshing and pampered. Some examples taken from the corpus are offered in (11) and (12) below:

$$
\begin{aligned}
& \text { Cocoa has many benefit effects. It has revitalizing, regenerative and } \\
& \text { moisturizing properties which comfort the body and delay the effects of } \\
& \text { aging on the skin, and at the same time, improves your emotional } \\
& \text { estate, reducing the stress and anxiety (airedesevilla.com/en/aire- } \\
& \text { services/thermal-bath-with-aromatherapy-and-chocotherapy). } \\
& \text { It moisturizes the airways and thins secretions } \\
& \text { (balneariodelanjaron.com). }
\end{aligned}
$$

On the other hand, recurring verbs evoking the desire to feel better are the following: bathe, capture, purify, protect, discover, reinvigorate, enjoy, feel, increase, relax, enrich, oxygenate, recover, improve and rejuvenate. We can illustrate this characteristic by means of some examples:

$$
\begin{aligned}
& \text { You will discover unique, new sensations. You will be soothed by } \\
& \text { relaxing music; perfumes and aromas will carry you back to bygone } \\
& \text { times (andalucia.org/en/health-and-beauty/arabic-baths). } \\
& \text { Purify your body and recover the wellbeing of body and mind } \\
& \text { (andalucia.org/en/health-and-beauty/spas). }
\end{aligned}
$$

Another resource is the use of ellipsis. The subject, which is omitted, often refers to the products or services advertised. Using ellipsis can make sentences short, concise, and can emphasize the key words and avoid redundancy. Ellipsis in advertising English is employed for vividness. In our corpus we can see the following examples: 
Relaxes and relieves muscular tension (It relaxes...) (airedealmeria.com).

$20 \%$ discount on advance sales. (Have a ...)

(granada.hammamalandalus.com).

Another feature is the use of auxiliary verbs like will or can. "Will" is used to evoke the impression of a promise. "Can" suggests what possibilities the product offers. Examples are the following:

$$
\begin{aligned}
& \text { You will discover unique, new sensations (andalucia.org/en/health-and- } \\
& \text { beauty/arabic-baths). }
\end{aligned}
$$

Hydrotherapy consists of treating the entire body with water at different temperatures. It can alleviate and even cure a wide range of illnesses through the pressure applied to the body (andalucia.org/en/health-and-beauty/therapeutic-treatments).

Another relevant and recurring peculiarity is the use of syntactic inversion to present the qualities of products like cosmetics or benefits of spas or baths. This technique creates expectation in the user and provokes desire to get the product or service:

Enriched with the thermal water of Alhama de Granada, the harpagophito cream is recommended for body massages (balnearioalhamadegranada.com).

Housed in caves in the town of Guadix, Hammam Kabir Arab Baths seek to recover the lost tradition of the hammam, or Arab baths, as a potent anti-stress therapy (granada.hammamalandalus.com).

Another tendency is the use of passive sentences. Although they are more frequent in formal language, they are used more often than it could be expected in this type of texts in order to convey prestige, like in the following examples:

$$
\begin{aligned}
& \text { These are the first Arab baths in Europe to be reopened following their } \\
& \text { closure in the 16th century. They are located at the foot of the } \\
& \text { Alhambra, on the ruins of an old hammam } \\
& \text { (granada.hammamalandalus.com). }
\end{aligned}
$$

This center has been recognized by the Spanish Tourist Quality Seal (balnearios.org/en/balneario/chiclana).

On the other hand, numbers are also used in our corpus. Cook (2001) recognised this resource in the transmission of advertising messages. The price of the product (massage, bath, etc.) is given, sometimes offering a discount, or a number is used to refer to the duration of a health programme or massage. This tendency to use 
figures to describe and define the product has a direct impact on the use of adjectives, normally used extensively in ads for consumer products in order to give product descriptions (Adams \& Cruz García, 2007).

(23) 7 night programme that combines balneotherapy with anti-aging medical therapy (balneariodelanjaron.com).

(24) Complete the bath and relaxing massage package by adding an extra 15 minutes to your massage (granada.hammamalandalus.com).

Bath with ritual al-andalus. Price: $55 €$

(granada.hammamalandalus.com)

A considerable number of examples in our corpus make use of several purpose structures to show the aim of either the products or services offered. Giving the customer the assurance that the method chosen will improve their health, beauty or wellness becomes compulsory in the advertised product. Look at the following patterns with examples:

a. Purpose: to + infinitive

To encourage relaxation and recover force and energy (balneariodelanjaron.com).

b. Purpose: in order to + infinitive

Modern techniques now complement the traditional baths in order to cater to guests of all ages (balnearioalhamadegranada.com).

c. Purpose: for + verb

Algae therapy: they are all excellent for recharging oligoelements (granada.hammamalandalus.com).

d. Purpose: for + noun

(29) The Hotel Balneario de Lanjarón ... was launched in 2012 to provide a complete quality service for wellness and relaxation (balneariodelanjaron.com).

e. Purpose clause: so that

(30) It comprises salts from mineral-medicinal waters from three of our springs providing the necessary balance so that the skin cells develop in perfect harmony (balneariodelanjaron.com). 


\subsection{Stylistic resources}

As to stylistic resources, metaphors, personifications, hyperboles and rhetorical questions are significant.

Metaphors are persuasive forms which are used to influence the decision of travellers by creating certain desires subliminally. They fulfil the following functions: appellative, emotive and poetic. There is a great number of them in this type of discourse. Here are some examples:

$$
\begin{aligned}
& \text { Welcome to the world of sensations. Beneath skies of stunning colour, with } \\
& \text { the energy of our very best medicine, the Sun, and the gentle caress of the } \\
& \text { sea breeze (andalucia.org/en/health-and-beauty). } \\
& \text { You will be soothed by relaxing music; perfumes and aromas will carry you } \\
& \text { back to bygone times; the mosaics, light and décor will captivate you } \\
& \text { (andalucia.org/en/health-and-beauty/arabic-baths). }
\end{aligned}
$$

Personifications are very common. Non-human objects like the health centre itself and even conditions of the body and mind, health, beauty or wellbeing are portrayed in such a way that we feel they have the ability to act like human beings. Examples taken from the corpus are the following:

$$
\begin{aligned}
& \text { Spa Resort San Andrés welcomes you to its website, from it you will get to } \\
& \text { know a place conceived for your enjoyment and health } \\
& \text { (balneariosanandres.com). } \\
& \text { Get carried away by a world where health, beauty and wellbeing are your } \\
& \text { host (andalucia.org/en/health-and-beauty). }
\end{aligned}
$$

Another stylistic feature is the use of hyperbolic expressions by means of superlative sentences, adjectives and adverbs. Their aim is to transmit appellative and emotive functions to this type of language and intensify attractiveness for tourists. Examples of this characteristic are the following:

$$
\begin{aligned}
& \text { It boasts the very latest in therapeutic spa facilities } \\
& \text { (balnearioalhamadegranada.com). }
\end{aligned}
$$

$$
\begin{aligned}
& \text { The mineral medicinal thermal waters that rise from the spring have } \\
& \text { been an endless source of health since ancient times } \\
& \text { (balnearioalhamadegranada.com). }
\end{aligned}
$$

Your skin will be fully primed for an aromatic massage of essential oils (granada.hammamalandalus.com).

Intended exaggeration is also communicated by means of non-gradable adjectives 
conveying the highest degree of intensity, like supreme, absolute, perfect, or essential. Look at the following examples taken from the corpus: supreme purification (balneariodelanjaron.com). a perfect sensation to stimulate yourself (granada.hammamalandalus.com).

a) an essential part of any Arab bath experience (andalucia.org/en/healthand-beauty/arabic-baths).

Finally, rhetorical questions are not very common in tourism discourse in general but in the promotion of health and beauty tourism they are easily found since they provoke customers' action, the last step in the selling power function (Leech, 1996). This linguistic device intends to encourage and convince customers to consume the goods advertised. Quirk et al. (1985, p. 825) reminds us that it is "a question which functions as a forceful statement". In other words, they are not real questions, as the answer is implicitly stated in the utterance (see examples 41 and 42 below):

$$
\begin{aligned}
& \text { For a relaxing end to a fun-packed day, what better than the marvellous } \\
& \text { SPA Elysium? (andalucia.org/en/articles/the-perfect-plan-for-lovers-of- } \\
& \text { golf-shopping-and-relaxing-days). } \\
& \text { In between your bath and massage, why not continue relaxing while } \\
& \text { savouring the tastes of a traditional Arabic drink, produced from a smooth } \\
& \text { and aromatic blend of green tea with mint? } \\
& \text { (granada.hammamalandalus.com). }
\end{aligned}
$$

According to our study, the linguistic characteristics which constitute the backbone of the promotion of health and beauty tourism texts are summarized in table 2:

\begin{tabular}{lll}
\hline Lex-morphological & Syntactic & Stylistic \\
\hline specialized vocabulary & imperatives & metaphors \\
\hline lexical collocations & present tense & personifications \\
\hline positive adjectives & ellipsis & hyperboles \\
\hline loan words & auxiliary verbs can, will & rhetorical questions \\
\hline blends & syntactic inversion & \\
\hline direct address using you & passive sentences & \\
\hline compound nouns & purpose structures & \\
\hline Acronyms & numbers & \\
\hline genre-mixing & & \\
\hline
\end{tabular}

Table 2. Lexical-morphological, syntactic and stylistic resources. 


\section{Conclusions}

In addition to magnificent beaches, history and culture, Andalusia also offers health and beauty centres where visitors can enjoy facilities that provide wellbeing. It offers a wide variety of spas, Arab baths, treatments and waters which complement a stay in which all aspects of rest and leisure can be satisfied. This paper has analyzed the discourse of the promotion of health and beauty tourism through websites from Andalusia with the aim of identifying its outstanding linguistic features, manifested at the lexical-morphological, syntactic and stylistic levels. These features are used as persuasive tools to influence potential tourists. Conditions of the body and mind, health, beauty or wellbeing are portrayed in such a way that we feel they turn into products which the potential tourist can "grasp". In this sense, the use of language is relevant to create host-tourist relations. The results of this study could be of relevance both to professional translators and particularly to students and teachers of translation, bearing in mind the emergence of health and beauty tourism as a new type of specialized discourse and the increasing probability that translators will be faced with texts of this nature. It is therefore important to consider the real-world circumstances that condition the production of this type of discourse, as discussed in section 2, and to become familiar with its specific lexical-morphological, syntactic and stylistic characteristics, as revealed and exemplified in the main part of the study. We also hope that the study may be used as a basis for creating activities in the translation classroom, for instance searching websites for examples of the various discourse features identified here, such as the use of technical and exotic lexis, hyperbole, synthetic personalization and so on. Similarly, students may use these classifications in order to contrast original and translated websites, with the aim of assessing the quality of the translations and in the process reinforcing their own knowledge and understanding of the genre.

\section{About the authors}

$\mathbf{M}^{\mathbf{a}}$ Enriqueta Cortés de los Ríos has been dealing with languages for Applied Purposes for the whole of her career, especially in the field of Economic and Business English. She is a lecturer at the Department of Philology, University of Almería (Spain). Her main areas of research interest are cognitive semantics, axiological linguistics, English for Specific Purposes (ESP) and didactics applied to languages for specific purposes. She teaches courses on cognitive semantics, axiology and ESP for postgraduate students. She has presented papers at different national and international conferences (among them, Ibérica, Revista Alicantina de Estudios Ingleses, The ESPecialist, LSP Professional 
Communication, Knowledge Management and Cognition, Revista de Lingüística y Lenguas Aplicadas, Revista de Lenguas para Fines Especificos, ESP Today). She is a reviewer for Iberica (AELFE) and she has occasionally been a coordinator and reviewer of Cognitive Linguistics and LSP panel of AELFE. She is also a member of a research group: Languages applied to professional and academic contexts, funded by the Regional Government of Andalucia, Granada University (HUM 641). She is an editor of Odisea, Revista de Estudios Ingleses edited by the Department of Philology, University of Almería.

Ana Corral Hernández is a lecturer of English as a first and second language and a member of the Department of English and German Studies in the Faculty of Translation and Interpreting at the University of Granada (Spain). Her specialized field of research was Descriptive Linguistics but later on her career took off on Languages and Didactics applied to Specific Purposes. She is also a member of the research group: Languages applied to professional and academic contexts, funded by the Regional Government of Andalucía, Granada University (HUM 641). It was mainly the development of a Teaching Innovation Project called: Autonomous learning of lexical specialized English for Tourism what meant the starting point of her interest in the field of study of the tourism industry. Other research contributions are related to the disciplines mentioned above: English as well as Spanish for Specific Purposes, namely Español para el Comercio Mundial del siglo XXI, El Inglés del futuro traductor e intérprete, Axiological analysis of print advertisements related to ecological issues in 'The Economist', The local context and its key role in the motivated learning of English for Tourism through Internet.

\section{LFE Article history}

Paper received: $20^{\text {th }}$ July 2015

Paper received in revised form and accepted for publication: $26^{\text {th }}$ October 2015

\section{References}

Adams, H. \& Cruz García, L. (2007). The Advertising of Financial Products in the Press. Ibérica, $13,123-146$.

Alcaraz Varó, E. (2000). El inglés profesional y académico. Alianza Editorial: Madrid. 
Borrueco, R. Ma . (2006). El discurso turístico: estudio lingüístico aplicado a la enseñanza de la traducción. Hieronymus Complutensis, 12, 69-78. Centro Virtual Cervantes.

Bowker, L. \& Pearson, J. (2002). Working with Specialized Language: A practical guide to using corpora. Londres: Routledge.

Cabré Castellví, T. (1993). La terminología: teoría, metodología, aplicaciones. Barcelona: Antártida.

Calvi, M. V. (2009). II discorso specialistico del turismo. In A. M. Di Liberti, V. Pecoraro \& O. Sacco (Eds.), Atti della Giornata di Studi "Lingue e linguaggi del turismo" (pp. 7-17). Palermo: Carbone Editore.

Cappelli, G. (2006), Sun, Sea, Sex and the Unspoilt Countryside. How the English language makes tourists out of readers. Paris: Paris Publishing.

Cappelli, G. (2008). The translation of tourism-related websites and localization: problems and perspectives. In A. Baicchi (Ed.), Voices on Translation (pp. 97-115) RILA Rassegna Italiana di Linguistica Applicata, Roma: Bulzoni Editore.

Cook, G. (2001). The discourse of advertising. London: Routledge.

Cortés de los Ríos, M. E. \& Azzahraa, F. (2014). The Construction of conceptual meaning in print footwear advertisements. LSP Journal, 5(2), 4-23.

Cruz García, L. \& Adams, H. (2005). La interacción de los códigos verbal e icónico en textos publicitarios: Implicaciones para la traducción. In L. Cruz García, V. M. González Ruiz, A. Monterde Rey \& G. Navarro Montesdeoca (Eds.), Traducir e Interpretar: Visiones, obsesiones y propuestas (pp. 259-68). Las Palmas de Gran Canaria: Servicio de Publicaciones de la Universidad de Las Palmas de Gran Canaria.

Cruz García, L \& Adams, H. (2006). Advertising Discourse: A Contrastive Analysis of Computer Adverts in English and Spanish. Revista de Lenguas para Fines Específicos, 11 y 12, 113-132.

Chaume Varela, F. \& Martí Ferriol, J.L. (2014). Teaching Advertising Translation: A Didactic Proposal. Revista Lingua, 1, 75-97.

Dann, G. (1996). The Language of Tourism: A Socio-linguistic Analysis. Wallingford: CAB International.

Dudley-Evans, T. \& St. John M. J. (1998). Developments in English for specific purposes: A multi-disciplinary approach. Cambridge University Press: Cambridge.

Fairclough, N. (1989). Language and Power. United Kingdom: Longman.

Folaron, D. 2006. A discipline coming of age in the digital age. In K. Dunne (Ed.), Perspectives on Localization (pp. 195-222). Amsterdam-Filadelfia: John Benjamins. 
Fuertes-Olivera, P.; Velasco-Sacristán, M.; Arribas-Baño, A. \& Samaniego-Fernández, E. (2001). Persuasion and advertising English: metadiscourse in slogans and headlines. Journal of Pragmatics, 33(8), 1291-1307.

Gotti, M. (2006). The Language of Tourism as Specialized Discourse. In O. Palusci \& S. Francesconi (Eds.), Translating Tourism. Linguistic/cultural representations (pp. 15-34). Trento: Editrice Università degli Studi di Trento.

Halliday, M.A.K.; McIntosh, A. \& Strevens, P. (1964). The linguistic sciences and language teaching. Longman: Londres.

Jiménez Crespo, M.A. (2008). El Proceso de Localización Web: Estudio Contrastivo de un Corpus comparable del Género Sitio. Tesis Doctoral. Granada: Universidad de Granada.

Jiménez Crespo, M.A. (2015). The Internet in translation education. In S. Colina \& C. Angelelli (Eds.), Translation and Interpreting Studies, 10(1), 33-57.

Leech, G. (1996). English in Advertising: A Linguistic Study of Advertising in Great Britain. London: Longman.

Mapelli, G. (2008). Las marcas de metadiscurso interpersonal de la sección 'turismo' de los sitios web de los ayuntamientos. In M. V.Calvi, G.Mapelli \& J. Santos (Eds.), Lingue, culture, economía: comunicazione e pratiche discorsive (pp. 173-190). Milano: Franco Angeli.

Merkaj, L. (2013). Tourist communication: a specialized discourse with difficulties in translation. European Scientific Journal, 2, 321-325.

Morgan, N. \& Pritchard, A. (2000). Advertising in tourism and leisure. Oxford: ButterworthHeinemann Publications.

Picken, C. (Ed.) (1989). The Translator's Handbook. London: Aslib.

Pierini, P. (2009). Adjectives in Tourism English on the Web. A corpus-based study. CÍRCULO de Lingüística Aplicada a la Comunicación (CLAC), 40, 93-116.

Priester, J.R. \& Petty, E.P. (2003). The influence of spokesperson trustworthiness on message elaboration, attitude strength, and advertising effectiveness. Journal of Consumer Psychology, 13, 408-21.

Quirk, R. et al. (1985). A Comprehensive Grammar of the English Language. London: Longman.

Salim, M.A.B.; Binti Ibrahim, N.A. \& Hassan, H. (2012). Language for Tourism: A Review of Literature. Social and Behavioral Sciences, 66, 136-143.

Schmidt, R. \& Kess, J. (1986). Television Advertising and Televangelism: Discourse Analysis of Persuasive Language. Amsterdam/Philadelphia: John Benjamins. 
Skibitska, O. (2013). The Translation of Tourism Websites. FLLT Conference Proceedings by LITU, 2(1), 735-740.

Suau Jiménez, F. (2012). Páginas web institucionales de promoción turística: el uso metadiscursivo interpersonal en inglés y español. In J. Sanmartín Sáez (Ed.), Discurso Turístico e Internet (pp.125-154). Madrid: Iberoamericana/Vervuert.

Tatilon, C. (1990). Le texte publicitaire: traduction ou adaptation? Meta XXXV (1), 243-246.

Torresi, I. (2007). Translating the Visual.The Importance of Visual Elements in the Translation of Advertising across Cultures. In D. Kenny \& K. Ryou (Eds.), Across Boundaries: International Perspectives on Translation Studies (pp. 38-55). Newcastle: Cambridge Scholars Publishing.

Valdés Rodríguez, C. (2013). Advertising Translation. In C. Millán \& F. Bartrina (Eds.), The Routledge Handbook of Translation Studies (pp. 300-314). Oxford y Nueva York: Routledge.

Zuliani, A. (2013). A journey to Portugal. The official tourist promotion of Turismo de Portugal. In E. Manca e F. Bianchi (Eds.), Tourism and Tourist Promotion around the World (pp. 61-80). Lecce: Università del Salento. Coordinamento SIBA. 